\title{
Advantages and Disadvantages of Using Webquests in Junior High School English Classes in Iran
}

\author{
Mahdi Amini (Corresponding author) \\ English Department, Najafabad Branch, Islamic Azad University, Najafabad, Iran \\ Email: mahdiamini1990@yahoo.com \\ Masoud Asgari \\ English Department, Najafabad Branch, Islamic Azad University, Najafabad, Iran \\ Zahra Asgari \\ PNU University, Isfahan Branch, Isfahan, Iran
}

Received: $14 / 02 / 2020$

Accepted: $15 / 05 / 2020$

Published: 20/05/2020

Volume: 1 Issue: 1

How to cite this paper: Amini, M., Asgari, M., and Asgari Z. (2020) Advantages and Disadvantages of Using Webquests in Junior High School English Classes in Iran. Journal of Critical Studies in Language and Literature, 1(1), 35-43

DOI: https://doi.org/10.46809/jcsll.v1i1.4

Copyright (C) 2020 by author(s) and Global Talent Academy Ltd. This work is licensed under the Creative Commons Attribution International License (CC BY 4.0).

http://creativecommons.org/licenses/by/4.0/

$$
\text { (c) (i) }
$$

\begin{abstract}
Webquest is an Internet-based learning and teaching tool, within which is a process involving students and teachers to use it for educational purposes. As an educational tool, the webquest has gained popularity in the education field across subjects and settings and is generally well-received by both teachers and students. Many junior high school English teachers use webquests to support modern teaching methods to improve students' instructions and learning processes in new opportunities of using webquest resources in English classes, as well. This study aimed at investigating the advantages and disadvantages of using webquests in Iranian junior high school English classes. This study also examined the application of webquests to motivate high school English teachers to teach more efficiently and provided the learners with a wonderful situation to learn English well. The present descriptive-analytical study was conducted in 2019 in four cities of Isfahan Province, Iran. The participants included 16 Iranian English teachers chosen based on the stratified random sampling method from junior high schools. The questionnaires and interviews were used to collect the data and the participants' insights about the advantages and disadvantages of using webquests in their English classes. Many English teachers considered webquests helpful and believed that it could help students do duties better and that the teachers could teach English more effectively and meaningfully. Webquest resources, likewise, help teachers work in groups and share ideas associated with the school curriculum.
\end{abstract}

Keywords: Webquest, Questionnaire, Educational technology, Iran

\section{Introduction}

Webquests incorporate technology with educational concepts by integrating online resources with student-centered and activity-based learning. According to Sunal and Haas (2002), webquests are problem-solving activities for students that 
incorporate the Internet, computer-based materials, and other available resources. Webquests provide the opportunity for students and teachers to actively engage in learning and teaching by connecting their interests with various content areas.

Oliver (2010) indicated that exposure to information through web sites can provide students with environments that support inquiry-based and constructivist learning. However, a large-scale study result indicated no effect of access to the Internet in school on students' achievement (Klein, 2006).

Webquest, an inquiry-oriented instructional template embedded with learning tasks, is necessary for improving students' learning. By webquest, students interact with resources on the Internet elicit students' higher-order thinking by analyzing the data for completing the task embedded in the webquest (Dodge, 1995). March (1998), the co-creator of webquest, indicated that it forces students to transform information into something else, a cluster that maps out the main issues, a comparison, a hypothesis, a solution, etc. Perkins and McKnight (2005) also explained that students have to evaluate the sites that are used for useful information while eliminating misinformation.

Webquest is one of the Internet-based learning tools that can be used for mastering the language. It can be considered an instructional aid and a tool for facilitating language teaching and learning (Sen \& Neufeld, 2006). Vanfossen (2005), when referring to the lack of Internet use by teachers, pointed out one possible reason for the lack of technology use in the classroom.

The results of this string of research confirm that technology can provide opportunities for influential teaching and learning environments (Hermans, Tondeur, van Braak, \& Valcke, 2008; Salehi, Asgari \& Amini, 2015; Yunus, Salehi, Amini, Shojaee, \& Fei, 2016; Yunus, Salehi, \& Amini, 2016;) and can affect students' learning (Cancannon, Flynn, \& Campbell, 2005), motivation (Mahdizadeh, Biemans, \& Mulder, 2008), critical thinking (Lim, Teo, Wong, Khine, Chai, \& Divaharan, 2003), and autonomy (Claudia, Steil, \& Todesco, 2004). In language learning, webquest not only allows students to construct their knowledge of the language structured web resources on their own (Laborda, 2009) but also helps students become better learners by increasing their autonomy and providing them a sense of fulfillment (Lou, 2010).

The present study aimed at investigating the advantages and disadvantages of using webquests in Iranian junior high school English classes.

\section{Literature Review}

In 1995, Dodge and March introduced webquests to the educational community. Dodge's article, "Webquests: A technique for Internet-based learning (Dodge, 1995)", allowed educators to see how the Internet could be used in classrooms for inquiry-based teaching and learning.

Webquests were defined as "an inquiry-orientated activity, in which some or all of the information that learners interact with, comes from resources on the Internet" (Dodge, 1995, p.10). Yoder (1999) explained that in a typical webquest, students were presented with a scenario and a task, usually a problem to solve or a project to complete. The students were given Internet resources and asked to analyze and synthesize the information and come up with their creative solutions. This explanation of webquests, along with the implementation by many teachers of webquests in their classrooms, often falls short of the true purpose and intended learning outcomes originally designed by Dodge and March (Barack, 2005; Dodge, 2001; March, 2004).

Authentic webquests require learners to take newly-acquired information and transform the information into authentic learning. Simply taking information from websites and putting the same information into a project does not allow the learner to transform the information into knowledge. March points out that getting the information, the learning input, is the easy part. The webquest gets trickier and more interesting materials in the next part, in which transformative learning takes place and teachers and students can realize or fail to realize the potential of a webquest $(2004$, p. 42).

Webquests should inspire students to seek themes among the information gathered from the website and, then, create projects and products that contribute to the real world of learning and allow students to reflect on their metacognitive processes (Dodge, 2001; March, 2004). Webquests have become an effective method of incorporating technology with educational concepts. In an interview, Dodge stated his intention for creating a webquest sparked from an interest in allowing his students to further connect with his in-class lesson (Starr, 2000).

A teacher conducting an online search of posted webquests will find many activities from all subjects and topics. Whether long-term or short-term quality webquests have certain critical attributes (Dodge, 1995). These attributes include an introduction, a task, information sources, process, evaluation, and conclusion (Table 1). Some attributes usually included, but not critical, in webquests are group activities and motivational elements. Besides, webquests can be interdisciplinary or within a single discipline.

According to March (1998), webquests increase students' motivation by providing an essential question, real-life resources with which to work and opportunities to work in cooperative groups. Webquests, by their nature, encourage the development of thinking skills. Because webquest tasks are often complex or involve controversial topics, students work in a group to complete tasks (March, 1998). Lipscomb (2003) made the following suggestions for implementing webquests:

1. Choose your webquest wisely.

2. Gauge student technology proficiency. 
3. Assess the availability of computers.

4. Have a backup plan.

5. Clarify students' roles.

6. Determine prior knowledge/content understanding.

7. Make assessment clear to students.

8. Maximize class time on the computer.

9. Be excited about the possibilities.

10. Continue working even after computer time is over.

The present study debates the topic under the following outlines:

- Advantages of webquests in enhancing qualified educational technology.

- Advantages of webquests for students.

- Advantages of webquests for teachers.

- Disadvantages of webquests for students.

- Disadvantages of webquests for teachers.

2.1 Advantages of webquests in enhancing qualified educational technology

Educational technology, like education in general, has greatly evolved. Just like the general population, the educational population gravitates toward new technologies. Today, the term educational technology covers various technologies being used by learners and teachers in the classrooms and everything from computers being used for word processing for the creation of webquests. Webquests should inspire students to seek themes among the information gathered from the website and, then, create projects and products that contribute to the real world of learning and allow students to reflect on their metacognitive processes (Dodge. 2001; March, 2004).

2.2 Advantages of webquests for students

1. Fun and students love them.

2. Student-centered.

3. Appeal to students' various learning styles (visual, audio, tactual, kinesthetic)

4. Provide efficient use of class time.

5. Help students meet learning competencies.

6. Encourage critical thinking skills.

7. Promote students' computer competency.

8. Help students focus on tasks.

9. Stimulate the learner's imagination.

10. Help students apply, synthesize, analyze, and evaluate what they are learning.

2.3 Advantages of webquests for teachers

1. A similar structure in all webquests.

2. Emphasis on teaching skills required to read webquests.

3. Encourages effective and structured use of Internet time (inquiry-based lessons/units are designed to guide students meaningfully).

4. Accommodates learners' diverse learning needs (individual and group work).

5. Keeping students on task in the class.

6. To ensure the teacher that all students are on the sites they should be on.

7. Teachers can address the goals of the Individualized Education Program (IEP) to focus on accommodations and modifications to support the student's success in the general curriculum.

8. Teachers can incorporate instructional support into the design of the webquest in the form of readability, larger text, and simpler directions.

9. Create the teachers' technical and information literacy skills synchronically.

10. Webquests cause the teachers to know new approaches and implements new instructions.

2.4 Disadvantages of webquests for students

1. Some webquests are not designed to meet the student-specific/provincial educational curriculum.

2. Access slow web connectivity and the inadequate number of computers.

3. Resource links readability often too high.

4. Creating own webquest requires time upgrading technical skills and information literacy skills.

5. Inflexible structure.

6. Difficult to search and find suitable Internet resources for students.

7. Webquests with too much integration may disclose too much information about students.

8. Students with limited technology skills will have difficulty completing the project.

9. Keeping students on task is a problem when using computers.

10. Require students to already have a certain level of English language abilities. 


\subsection{Disadvantages of webquests for teachers}

1. Teachers are hesitant to try new approaches like implementing a webquest.

2. Creating a webquest would require time to upgrade the teachers' technical and information literacy skills.

3. Difficult for the teacher to ensure that all students are on the sites they should be on.

4. The structure of the webquest is inflexible and does not allow teachers to be creative.

5. Webquest are very informal and do not provide enough teaching material.

6. The teacher will not teach with webquests since he/she has a very heavy teaching workload.

7. Webquests can create some space for teachers to exchange their viewpoints.

8. Some of the teachers are not familiar with this format and it can be a waste of time for them.

9. It is difficult to search and find suitable Internet resources for teachers.

10. The teachers, who wish to use webquests may need additional training.

\section{Methodology}

The present descriptive-analytical study was conducted in 2019 in four cities of Isfahan Province, Iran. The participants included 16 Iranian English teachers chosen based on stratified random sampling method from Junior high schools. Three male (37.5\%) and five female (62.5\%) English teachers were selected randomly from the population. The following instruments were used to collect the data:

\subsection{Personal Information Form}

Using a personal information form, the teachers' features were collected. The teachers were requested to provide information about personal variables such as academic degree, gender, age, years of experience, and area of teaching. The reliability and validity of this questionnaire have already been confirmed.

3.2 Role of Using Webquests in Teaching English Classes in Iran

In general, seven strategies were applied to assess the role of using webquests in teaching English classes in Iran. The statements were designed based on 5-point Likert scale (never $=1$, rarely $=2$, sometimes $=3$, often $=4$, and always $=5$ ). The reliability of this questionnaire was 0.79 based on the test-retest method. Moreover, the validity of this questionnaire was confirmed by a panel of experts.

\subsection{Advantages of Using Webquests in Teaching English Classroom Form}

Attitudes toward the advantages of information communications technology tools in teaching English classrooms were assessed by 17 items. The statements were designed based on 5 -point Likert scale (strongly disagree $=1$, disagree $=2$, neutral $=3$, agree $=4$, and strongly agree $=5$ ). The reliability of this questionnaire was 0.82 based on the test-retest method. Furthermore, the validity of this questionnaire was confirmed by a panel of experts.

3.4 Disadvantages of Using Webquests in Teaching English Classroom Form

Attitudes toward the disadvantages of using webquests in teaching English classrooms were assessed by 17 items. The statements were designed based on 5-point Likert scale (strongly disagree $=1$, disagree $=2$, neutral $=3$, agree $=4$, and strongly agree $=5$ ). The reliability of this questionnaire was 0.79 based on the test-retest method. Besides, the validity of this questionnaire was confirmed by a panel of experts.

The questionnaires were administered in high schools named Andisheh, Razi, Sina, Farabi, Dr. Hesabbi, Dr. Abbedi, Hafez, and Saadi. The questionnaires were immediately retrieved from the respondents (Table 2). The participants were assured that the information would be confidential and would be used only for research purposes. Moreover, to preserve their privacy, their names and surnames were not recorded. The participants were assigned a code to preserve their identity (N1, N2. etc.).

All ethical principles were considered in this article. The participants were informed about the purpose of the research and its implementation stages and signed the informed consent. Moreover, they were allowed to leave the study whenever they wish and, if desired, the results of the research would be available to them.

\section{Results}

Table 1. Key webquests components

\begin{tabular}{ll}
\hline Components & \multicolumn{1}{c}{ Functions } \\
\hline Introduction & It provides background information on the topic and sets the stage for the investigation or activity. \\
\hline Task & $\begin{array}{l}\text { It includes an activity that is doable and is of interest to the students often identifies roles for cooperative group } \\
\text { members. }\end{array}$ \\
\hline Resources & It provides links to high-quality Internet-based resources that students will use to complete the activity; links \\
\hline
\end{tabular}


might be embedded in the process.

Process It provides a step by step guide for the completion of the activity and provides a clear description of exactly what students should do to complete the task.

Evaluation It should illustrate exactly what students should do to be successful, usually in the form of a rubric or checklist.

Conclusion It brings closure to the activity and summarizes what you hope the students have learned as a result of completing the activity.

Table 1 shows key webquest components, including introduction, task, resources, process, evaluation, and conclusion. In this table, their functions are important in the process of using webquest in English classes.

Table 2. Junior high schools involved in the research

\begin{tabular}{lc}
\hline Name of junior high schools & Number of questionnaires \\
\hline Andisheh & 15 \\
\hline Razi & 12 \\
\hline Sina & 11 \\
\hline Farabi & 10 \\
\hline Dr. Hesabbi & 11 \\
\hline Dr. Abbedi & 11 \\
\hline Hafez & 10 \\
\hline Saadi & 10 \\
\hline
\end{tabular}

Table 2 reveals eight schools in this research. Five of the schools were girls' schools and three of them were boys' schools; 16 questionnaires were distributed among the participants.

Table 3. Number of distributed and collected English teachers' questionnaires

\begin{tabular}{ccccc}
\hline Schools & Gender & Distributed questionnaires & Collected questionnaires & Involvement (\%) \\
\hline Andisheh & Girl & 15 & 13 & 86.66 \\
\hline Razi & Girl & 12 & 8 & 66.66 \\
\hline Sina & Girl & 11 & 9 & 81.81 \\
\hline Farabi & Boy & 10 & 8 & 80 \\
\hline Dr. Hesabbi & Girl & 11 & 9 & 81.81 \\
\hline Dr. Abbedi & Boy & 11 & 10 & 90.90 \\
\hline Hafez & Boy & 10 & 10 & 100 \\
\hline Saadi & Girl & 10 & 9 & 90 \\
\hline Total & & 90 & 76 & 84.44 \\
\hline
\end{tabular}

Among the distributed questionnaires, some were incomplete. Table 3 presents the high school types, the gender of the junior high schools, distribution questionnaires, and the collected questionnaires. All schools were governmental. The maximum percent belonged to Dr. Abeddi high school $(90.90 \%)$ and the minimum percent belonged to Razi high school $(66.66 \%)$. 
Table 4. Role of using webquests in teaching English classes

\begin{tabular}{|c|c|c|c|c|c|c|c|c|c|c|c|}
\hline Strategies & $\frac{8}{5}$ & s సี - & $\stackrel{\widetilde{a}}{\tilde{\Xi}}$ & 预 & $\stackrel{\mathscr{e}}{1}$ & $\begin{array}{ll}\ddot{c} \\
\Rightarrow\end{array}$ & 華烍 & N & & $\theta \stackrel{0}{0} \pi$ & de \\
\hline Create a webquest to learn about webquest & 8 & 8 & 9 & 7 & 9 & 10 & 10 & 0 & 9 & 70 & 77.77 \\
\hline Create a webquest to teach students about it & 11 & 7 & 8 & 7 & 9 & 9 & 11 & 1 & 9 & 71 & 78.88 \\
\hline Create a webquest to teach content & 13 & 8 & 8 & 8 & 8 & 9 & 10 & 0 & 8 & 72 & 80 \\
\hline Create a webquest for a class assignment & 10 & 6 & 9 & 7 & 8 & 8 & 9 & ) & 6 & 63 & 70 \\
\hline Create a webquest for portfolio & 6 & 8 & 9 & 7 & 7 & 9 & 7 & 7 & 8 & 61 & 67.77 \\
\hline Create a webquest for fun & 11 & 8 & 7 & 8 & 9 & 10 & 11 & 1 & 8 & 72 & 80 \\
\hline Create a webquest for experiment & 13 & 8 & 9 & 9 & 9 & 10 & 10 & 0 & 9 & 77 & 85.55 \\
\hline Create a webquest to use in teacher coaching & 9 & 7 & 8 & 9 & 8 & 9 & 6 & 5 & 8 & 64 & 71.11 \\
\hline
\end{tabular}

Table 4 shows the rate of using different strategies in different high schools by the role of using webquests in teaching English classes. "Create a webquest to teach content", "Create a webquest for fun", and "Create a webquest for experiment" were the most popular strategies, on which English teachers agreed.

Table 5. Advantages of using webquest facilities

\begin{tabular}{|c|c|c|c|c|c|c|c|c|c|c|c|}
\hline Advantages of webquests & $\frac{\mathscr{\theta}}{\mathscr{a}}$ & s స్ & $\stackrel{\pi}{\Xi}$ & 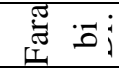 & $\underset{\mathbb{1}}{\mathbb{I}}$ & it & $\ddot{7}$ & N & $=\stackrel{0}{0}$ & $0 \pi$ & $a^{e}$ \\
\hline Fun and students love them & 13 & 8 & 8 & 9 & 9 & 10 & 10 & 9 & 9 & 76 & 84.44 \\
\hline Motivate students & 12 & 8 & 9 & 9 & 9 & 9 & 9 & 9 & 9 & 74 & 82.22 \\
\hline Provide hands-on activities & 10 & 7 & 8 & 8 & 8 & 10 & 10 & 9 & 9 & 70 & 77.77 \\
\hline Help students focus on tasks & 13 & 8 & 9 & 9 & 8 & 9 & 10 & 9 & 9 & 75 & 83.33 \\
\hline Promote collaborative learning & 13 & 8 & 8 & 8 & 9 & 9 & 9 & 8 & 8 & 72 & 80 \\
\hline Help students complete the assignments & 12 & 7 & 7 & 9 & 8 & 10 & 9 & 7 & 7 & 69 & 76.66 \\
\hline Are student-centered & 9 & 7 & 7 & 9 & 8 & 10 & 8 & 8 & 8 & 66 & 73.33 \\
\hline Encourage critical thinking skills & 12 & 6 & 9 & 8 & 9 & 9 & 9 & 9 & 9 & 71 & 78.88 \\
\hline Provide scaffold content and clear directions & 10 & 8 & 8 & 9 & 9 & 9 & 10 & 8 & 8 & 71 & 78.88 \\
\hline
\end{tabular}

Table 5 indicates the advantages of using webquest facilities. The maximum beliefs belonged to "Fun and students love them" $(84.44 \%)$, but the minimum beliefs belonged "Are student-centered" $(73.33 \%)$.

Regarding the advantages of using webquests, it was reported that using webquests could help meet the teachers' teaching objectives as webquest aids the teaching process. The results of the study revealed that English teachers used technology chiefly in teaching, followed by all fundamental skills and some English categories as pronunciation.

N10 stated "Students considered that the webquest significantly enhanced their learning. Promising directions for future development are also identified. Of course, scientific tasks help students develop their skills in gathering data and it can help the teacher to check the time and control the students better" when he was asked "How is the webquest keeping the students on task in the class?".

In response to the question "Why is the webquest fun for the students?", N2 stated that "Because students learn more detailed information about a specific topic and create a greater sense of importance for that topic. It can help them get the information correctly and motivate them to learn better, as well".

Besides, N4 answered the question "How can the webquest help the students focus on tasks?" in this way: "Webquests are designed to use learners' time well, to focus on getting and using information rather than looking for it, and to support learners' thinking, ideas and viewpoints at the levels of analysis, synthesis, and evaluation. Webquests are appealing because they provide structure and guidance for students". 
In response to the question "How can the webquests cause the teachers to know new approaches and instructions?", N5 replied "Webquests are designed to ensure meaningful learning by combining technology with a constructivist approach in the classroom setting. Therefore, the webquest, by using strategy, has a positive impact on the student learning retentions".

The outcomes of the current study also showed that webquest tools such as Internet rules, online databases, online weblogs, websites, and social networking sites are almost less used in schools of Iran in general and in junior high school English classes in particular and when they are used, they can be distracting.

N9 said "Sometimes, just reading and then answering could be boring. The students easily get distracted when using webquest items like Google, Yahoo, Telegram, and Facebook! Webquests have inflexible structure and the low speed of the Internet or lack of access to the Internet can be annoying." in response to the question "Is the webquest boring for the students?"

\section{Discussion}

The present research aimed at investigating the advantages and disadvantages of using webquests in Iranian junior high school English classes. The application of webquests to motivate high school English teachers to teach English more efficiently was also considered. This descriptive-analytical study was conducted in 2019 on the Iranian English teachers, who were corresponding in their general attainment in keeping with the statistical treatment in junior high schools.

In line with some studies on the effectiveness of webquest (Monroe \& Orme, 2005; Asgari \& Salehi, 2018), the present study concluded that webquest had a positive impression on the teachers' teaching skills. The researchers attributed these findings to the advantages of the webquest as a teaching/learning strategy.

Although this study addressed the advantages and disadvantages of using webquests in Iranian junior high school English classes, the benefits and issues were common to many specialized fields, as well as to general English.

Furthermore, the authors believed that webquests should not be seen as the foremost learning tool in English for specialized purposes. It was clearly shown that webquests could be treasured tools for providing teachers and students with many collaboration opportunities in realistic settings, thereby making the learning experience meaningful, empirical, and motivating.

Besides, webquest has brought two types of benefits to the teachers: 1) the teachers' professional capabilities in the use of both computers and Internet; 2) the upgrading of their teaching skills in aspects such as enthusiasm, leadership, organization, respectfulness, multitasking, teamwork, ability to teach, communication, adaptability, interpersonal skills, creativity, selfevaluation, patience, and emotional intelligence while working on a foreign language teaching.

Moreover, the findings indicated that English teachers have formulated a selective webquest use strategy based on the nature of language skills/components. They teach with a general tendency to use digital portable devices and websites resources, as well.

\section{Conclusions}

Many English teachers have considered webquests an effective channel for both teaching and learning. Webquest resources, likewise, help teachers work in groups and share ideas associated with the school curriculum. Many junior high school English teachers use webquests to support and improve students' learning.

\section{Acknowledgements}

The authors of the article would like to thank the cooperation and assistance of all those, who helped us in this research. In this study, all relevant ethical principles, including the confidentiality of the questionnaires, the informed consent of the participants in the research, and the freedom to leave the research were observed.

\section{References}

Barack, L. (2005). Webquest Blossoms. School Library Journal. 51 (9). 26.

Cancannon, F., Flynn, A., \& Campbell, M., (2005). What Campus-Based Students Think about the Quality and Benefits of ELearning. British Journal of Educational Technology. 36 (3). 501-512. doi:10.1111/j.1467-8535.2005.00482.x, http://dx.doi.org/10.1111/j.1467-8535.2005.00482.x.

Claudia, M., Steil, A., \& Todesco, J. (2004). Factors Influencing the Adoption of the Internet as a Teaching Tool at Foreign Language Schools. Computers \& Education. 42 (4). 353-374. doi:10.1016/j.compedu.2003.08.007, http://dx.doi.org/10.1016/j.compedu.2003.08.007. 
Dodge, B. (1995). Webquests: A Technique for Internet-Based Learning. The Distance Educator. 1 (1). 10-13.

Dodge, B. (1995). Some Thoughts about WebQuests. San Diego: University of San Diego. https://www.scirp.org/(S(351jmbntvnsjt1aadkposzje))/reference/ReferencesPapers.aspx?ReferenceID=652651

Dodge, B. (2001). FOCUS: Five Rules for Writing a Great Webquest. Learning \& Leading with Technology. 28 (8). 6-9.

Hermans, R., Tondeur, J., Van Braak, J., \& Valcke, M. (2008). The Impact of Primary School Teachers' Educational Beliefs on the Classroom Use of Computers. Computers \& Education. 51 (4). 1499-1509. doi:10.1016/j.compedu.2008.02.001, http://dx.doi.org/10.1016/j.compedu.2008.02.001.

Klein, C. (2006). Virtual Charter Schools and Home Schooling. New York: Cambria Press. https://books.google.com/books?id=khO6zSXqzosC\&dq

Lim, C. P., Teo, Y. H., Wong, P., Khine, M. S., Chai, C. S., \& Divaharan, S. (2003). Creating a Conducive Learning Environment for the Effective Integration of ICT: Classroom Management Issues. Journal of Interactive Learning Research. 14 (4). 405-423.

Lipscomb, G. (2003). “I Guess It Was Pretty Fun” Using Webquests in The Middle School Classroom. The Clearing House. 76 (3). 152-155. doi:10.1080/00098650309601993, https://doi.org/10.1080/00098650309601993.

Laborda, JG. (2009). Using Webquests for Oral Communication in English as a Foreign Language for Tourism. Educational Technology \& Society. 12 (1). 258-270.

Lou, M. (2010). An Experimental Study on Webquest in Promoting Non-English Majors' Learner Autonomy. Journal of Heilongjiang College of Education. 29 (4). 148-150.

Mahdizadeh, H., Biemans, H., \& Mulder, M. (2008). Determining Factors of the Use of E-Learning Environments by University Teachers. Computers \& Education. 51 (1). 142-154. doi:10.1016/j.compedu.2007.04.004, http://dx.doi.org/10.1016/j.compedu.2007.04.004.

March, T. (1998), Why webquests? An introduction Webquest for Learning Web-site. [Online] Available: https://tommarch.com/writings/why-webquests/ (April 20, 1998)

March, T. (2004). The learning powers of Webquests. Educational Leadership. 61 (4). 42-47.

Orme, M. P., \& Monroe, E. E. (2005). The Nature of Discourse as Students Collaborate on a Mathematics WebQuest. Computers in the Schools. 22 (1-2). doi:10.1300/J025v22n01_12, https://doi.org/10.1300/J025v22n01_12.

Oliver, D. (2010). The Effect and Value A Webquest Activity on Weather in 5th Grade Classroom. Ann Arbor: ProQuest Dissertation Publishing.

Perkins, R., \& McKnight M. L. (2005). Teachers' Attitudes Toward WebQuests as a Method of Teaching. Computers in the Schools. 22 (1). 123-133. doi:10.1300/J025v22n01_11, https://doi.org/10.1300/J025v22n01_11.

Salehi, H., \& Asgari, M. (2018). Impact of Using Web-quests on Learning Vocabulary by Iranian Pre-university Students. International Journal of Foreign Language Teaching and Research. 6 (22). 33-46. http://jfl.iaun.ac.ir/article_601179.html.

Salehi, H., Asgari, M., \& Amini, M. (2015). Merits and Demerits of Using Information and Communication Technology (ICT) Tools in Iranian Junior High School English Classes. The Journal of Global Academic Institute Education \& $\begin{array}{lllll}\text { Social } & \text { Sciences. } & 1 & \text { (2). } & \text { 140-150. }\end{array}$ content/uploads/jgaiess_vol_1_no_2.pdf

Sen, A., \& Neufeld, S. (2006). In Pursuit of Alternatives in EFL Methodology: Webquests. The Turkish Online Journal of Educational Technology. 5 (1).

Starr, L. (2000), Meet Bernie the Frank L. Ioyd Wright of Learning Environments. [Online] Available: https://www.educationworld.com/a_issues/chat/chat015.shtml (February 2, 2012)

Sunal, C., \& Haas, M. (2010). Social Studies for the Elementary and Middle Grades: A Constructivist Approach. (4th ed.). Amsterdam:

Pearson, https://books.google.nl/books/about/Social_Studies_for_the_Elementary_and_Mi.html?id=6O4SQgAACAAJ\&redir _esc $=$ y

VanFossen, P. J. (2005). Student and Teacher Perceptions of the Webquest Model in Social Studies: A Preliminary Study. Paper Presented at the College and University Faculty Assembly at the National Council for the Social Studies Annual Meeting in Kansas City, MO. November 17, 2005. 
Yoder, M. B. (1999). The Student Webquest: A Productive and Thought-Provoking Use of the Internet. Learning and Leading with Technology. 26 (7). 6-9.

Yunus, M. M., Salehi, H., \& Amini, M. (2016). Impact of Using CALL on Iranian EFL Learners' Vocabulary Knowledge. English Language Teaching. 9 http://www.ccsenet.org/journal/index.php/elt/article/view/55692. doi:10.5539/elt.v9n1p173,

Yunus, M. M., Salehi, H., Amini, M., Shojaee, M., \& Fei W. Y. (2016). Activities and Suggestions for Using Social Networking in Teaching ESL Writing. Journal of Theoretical and Applied Information Technology. 84 (2). $170-182$. http://www.jatit.org/volumes/Vol84No2/3Vol84No2.pdf 